\title{
EFEKTIVITAS MODEL PRAKARYA DAN KEWIRAUSAHAAN BERBASIS EKONOMI KREATIF BERDIMENSI INDUSTRI KEUNGGULAN LOKAL TERHADAP KEINOVATIFAN SISWA
}

\author{
Sukardi \\ FKIP Universitas Mataram \\ e-mail: sukardi@unram.ac.id
}

\begin{abstract}
Abstrak: Penelitian ini bertujuan untuk mengetahui keefektifan model pendidikan Prakarya dan Kewirausahaan berbasis ekonomi kreatif berdimensi industri keunggulan lokal terhadap keinovatifan siswa SMA dalam menghasilkan produk/jasa. Penelitian berupa penelitian dan pengembangan versi Borg dan Gall yang dipadukan dengan prinsip desain konstruktivistik. Kajian dilakukan melalui tahapan uji produk awal melalui uji terbatas yang disertai revisi; uji produk akhir melalui quasi eksperimen; dan desiminasi dan implementasi. Data dikumpulkan melalui tes, proyek, dan kuesioner, sedang analisis data dilakukan lewat uji korelasi dan t-tes. Hasil penelitian menunjukkan: (1) hasil uji produk awal menunjukkan bahwa model yang dihasilkan sangat baik dan layak diuji lebih lanjut; (2) hasil uji produk akhir menunjukkan model yang dihasilkan efektif ditinjau dari keinovatifan siswa dalam menghasilkan produk ekonomi kreatif berdimensi keunggulan lokal; (3) guru dan siswa memberikan respon yang sangat baik terhadap model yang dihasilkan dilihat dari aspek relevance, reflection, interaction, tutor support, peer support, dan interpretation; (4) model akhir yang dihasilkan memuat tiga komponen utama, yaitu tujuan, prosedur, dan penilaian pembelajaran.
\end{abstract}

Kata Kunci: efektivitas model, prakarya dan kewirausahaan, keinovatifan

\section{THE EFFECTIVENESS OF CRAFTSMANSHIP EDUCATIONAL MODEL AND CREATIVE ECONOMY-BASED ENTREPRENEURSHIP WITH LOCAL ADVANTAGE INDUSTRY TO STUDENTS' INNOVATION}

\begin{abstract}
The purpose of this study is to figure out the effectiveness of craftsmanship educational model and creative economy-based entrepreneurship with local advantage industry to the level of high school students' innovation in providing products / services. This study uses a model of research and development developed by Borg and Gall combined with constructivist design principles. The second phase involves two steps: (1) the initial product test through limited testing with revisions; (2) the final product test through a quasi-experimental; and (3) the dissemination and implementation. The results of the study are : (1) the results of the initial product test show that the model produced is excellent and feasible for a further research; (2) the results of thefinal product test show that the model produced is effective as it promotes students' innovation in producing creative economy based entrepreneurship with local advantage industry; (3) teachers and students respond very well to the model generated from the aspects of relevance, reflection, interaction, tutor support, peer support, and interpretation; (4) the final model generated contains three main components; the objectives, procedures, and assessment of learning.
\end{abstract}

Keywords: Effectiveness Model, Crafts and Entrepreneurship, Innovation

\section{PENDAHULUAN}

Tulisan ini merupakan kelanjutan tulisan Sukardi (2016). Tulisan ini menfokuskan pada keefektifan model dengan menggunakan keinovatifan siswa sebagai parameternya, karena keinovatifan merupakan salah satu karakteristik entrepreneur (Deveci \& Çepdi, 2015:135; Rauch \& Frese, 2007:353; Altinay dkk., 2012; dan Zimmerer dkk., 2008:43), di samping kebutuhan berprestasi, pengambilan risiko, internal locus of control, dan keproaktifan (Murwani, 2016:45-46). Karakter keinovatifan menurut Rauch dan Frese (2007:353) tercermin dari kemampuan seorang entrepneur dalam menghasilkan produk baru, proses baru dalam berproduksi, menemukan pasar baru, dan menggunakan teknologi baru bagi perusahaannya (usahanya). Untuk mencapai inovasi, maka disyaratkan adanya kemampuan 
berfikir kreatif entrepneur, karena kreativitas menurut West (2002) adalah pengembangan ideide baru dan bernilai, sementara inovasi merupakan implementasi dari ide-ide baru dan bernilai menjadi produk. Selain itu, hasil konstruksi yang dibangun Macdonald (2013) dan Rautkorpi (2007) menyebutkan bahwa karakter entrepneur tersebut sejalan tuntutan ekonomi kreatif yang menempatkan kreatifitas manusia sebagai faktor produksi utama dalam kegiatan ekonomi. Dalam kajiannya, Rautkorpi (2007:231) menyatakan bahwa ekonomi kreatif menjadi trend ekonomi dan bisnis baru di Finlandia.

Oleh karenanya, penguatan karakter keinovatifan siswa melalui pendidikan (kewirausahaan) menjadi sangat relevan, apalagi jika berkaca dari permasalahan lulusan jenjang SMA, seperti: pengangguran mencapai 1,546, 699 orang (BPS, 2016a) dan tidak melanjutkan studi ke Perguruan Tinggi (PT), yang terindikasi pada Angka Partisipasi Kasar PT yang baru menyentuh 20,89\% (BPS, 2016b). Hal ini sejalan dengan apa yang disampaikan oleh Drucker (1985:18) sebagaimana dikutip Kuratko (2005) dan Murwani (2016:12) bahwa "the entrepreneurial mystique? It's not magic, it's not mysterious, and it has nothing to do with the genes. It's adiscipline. And, like any discipline, it can be learned".

Permasalahannya, praktik pendidikan kewirausahaan menunjukkan beberapa kelemahannya, seperti: tujuan dan isi pembelajaran di sekolah masih konseptual (isinya tidak terkait kebutuhan dan potensi/industri keunggulan lokal), metode pembelajaran cenderung ceramah dan penilaian bersifat tertulis yang hanya mengukur kognitif. Oleh Murwani (2016: 38) disebabkan karena praktik pendidikan kewirausahaan masih sebatas teaching about entrepreneurship bukan teaching for entrepreneurship, apalagi teaching through entrepreneurship.

Dengan demikian, membentuk keinovatifan Siswa idealnya dimulai dengan membenahi pendidikan kewirausahaan, karena pendidikan kewirausahaan itu menurut Murwani (2016:12) sangat erat dengan sasaran/tujuan (objective), isi (content), pebelajar (audience), metode (method), dan evaluasi (evaluation). Kelima aspek tersebut diistilahkan oleh Byrne dkk. (2014:261-288) dalam bentuk pertanyaan, yaitu: why (tujuan/ sasaran), what (isi), for whom (pebelajar), how (metode), dan for which results (evaluasi). Karena keinovatifan menjadi sentral, maka sasaran- nya (Murwani, 2016:14) atau tujuan menurut istilah Fayolle (2008) menjadi fokus utama sehingga harus relevan dengan kebutuhan, permasalahan, dan potensi sumber daya sekitarnya sebagaimana pemikiran teori rekonstruksi sosial (McNeil, 2006:36). Rekonstruksi sosial tidak hanya berupaya menyadarkan tentang problem sosial siswa, melainkan juga menjadi solusi terhadap pemecahan permasalahan sosial (McNeil, 2006:37) dengan memanfaatkan potensi atau keunggulan sekitar siswa. Salah satu bentuk solusi adalah melalui pembenahan pembelajaran yang tidak hanya melalui interaksi dan kerjasama (Man \& Yu, 2007:628-629; Jha, 2012:175-177), melainkan melalui praktik kewirausahaan (Mayhew dkk., 2016:425-426; Solomon, 2007:176177); Vanevenhoven, 2013:377). Dengan pola tersebut, maka diharapkan pendidikan kewirausahaan tidak hanya sampai pada teaching about entrepreneurship, melainkan menjadi teaching for entrepreneurship bahkan teaching through entrepreneurship.

Secara khusus kajian tahap kedua ini bertujuan untuk mengetahui keefektifan model pendidikan Prakarya dan Kewirausahaan berbasis ekonomi kreatif berdimensi industri keunggulan lokal jenjang SMA. Keefektifan diukur dari ketercapaian keinovatifan Siswa dalam menciptakan/ menghasilkan produk/jasa.

\section{METODE}

Kajian ini juga menggunakan model research and development (Borg \& Gall, 1983:775) yang dikombinasikan dengan prinsip-prinsip desain berorientasi konstruktivistik (Willis, 2000:912). Kajian ini difokuskan pada pengujian model sebagaimana ditunjukkan pada Gambar 1 .

Uji produk awal dilakukan melalui uji coba terbatas. Uji ini dilakukan melalui tindakan atau kegiatan pembelajaran secara terus-menerus dan bersiklus. Dalam setiap siklus terdiri dari empat tahapan utama, yaitu: perencanaan, pelaksanaan, observasi, dan refleksi. Uji coba terbatas lebih bersifat perbaikan terhadap draft model. Namun demikian, sebelum dilakukan uji coba terbatas terlebih dahulu dilakukan uji formatif. Uji formatif dilakukan dengan melibatkan siswa untuk menilai aspek kemenarikan, keterbacaan, dan kemudahaan memahami model, khususnya produk buku ajar.

Tahap uji produk akhir dilakukan melalui uji lapangan pada setiap kluster industri kreatif 
(kabupaten/kota) dalam bentuk quasi eksperimen. Rancangan yang digunakan adalah nonequivalent control group design (Borg \& Gall, 1983:682; Ary dkk., 2002:316). Untuk mengurangi kelemahan desain quasi eksperimen ini, dilakukan penyepadanan subjek (kelas eksperimen dan kontrol), yaitu: IQ, minat wirausaha, prestasi belajar, sarana dan prasarana (selain yang disiapkan), jumlah siswa, kemampuan dan kesungguhan guru yang mengajar, dan alokasi waktu dan jadwal pembelajarannya, serta instrumen evaluasi kelas kontrol disiapkan peneliti.

Data keinovatifan Siswa diukur menggunakan instrumen penilaian berbasis proyek dan kuesioner sebagaimana digunakan juga dalam kajian-kajian sebelumnya. Penilaian berbasis

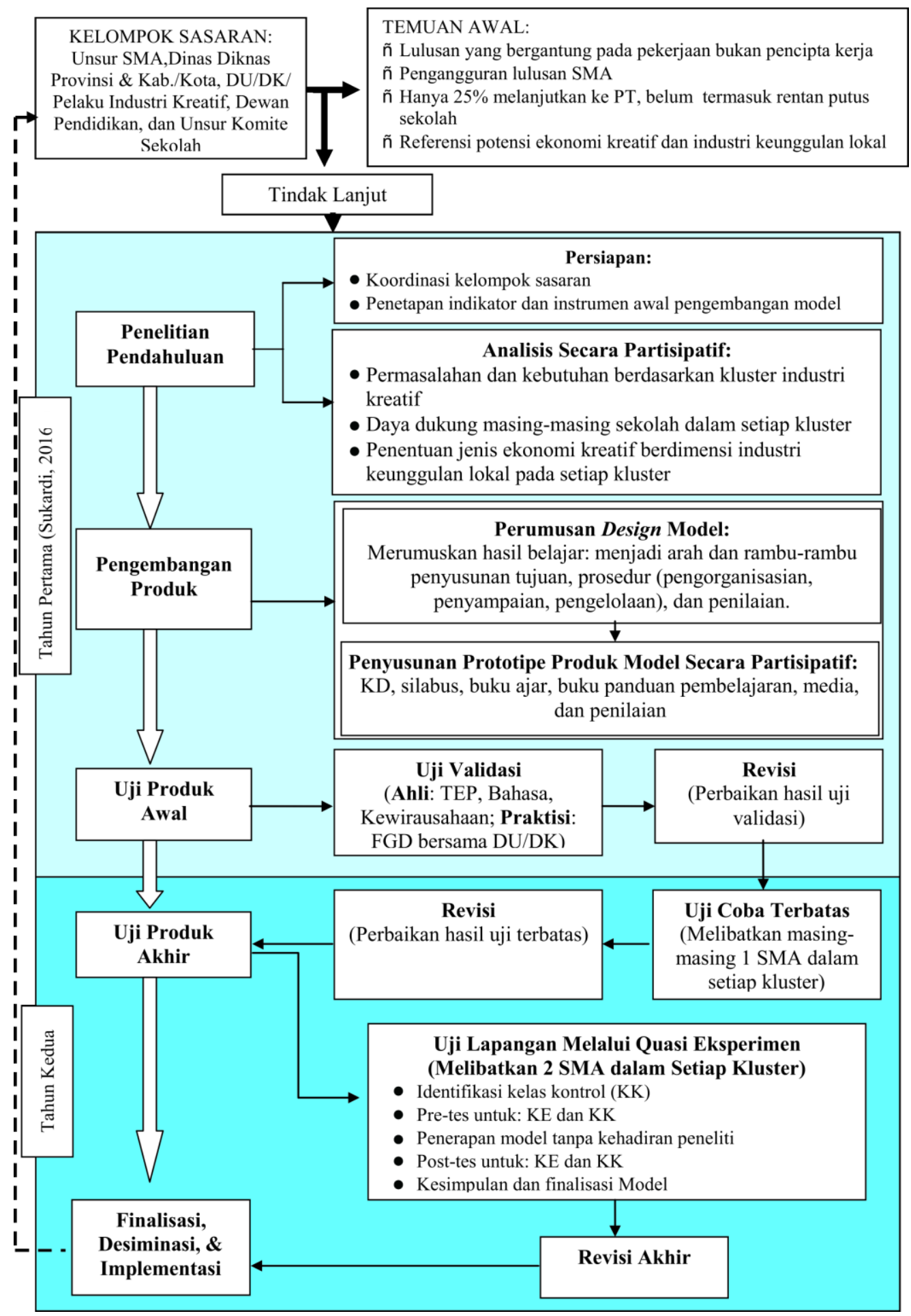

Gambar 1. Alur Penelitian dan Pengembangan (Sukardi, 2016) 
proyek mencakup perencanaan, pelaksanaan, produk/hasil, dan pelaporan/penyajian (Bergh dkk., 2006; Puskur Balitbang, 2006:36). Kuesioner digunakan untuk mengetahui tanggapan Siswa dan guru terhadap model yang dihasilkan dengan menggunakan instrumen yang dikembangkan oleh Sthapornnanon dkk (2009) yang mencakup: relevance, reflection, interaction, tutor support, peer support, dan interpretation. Kedua instrumen juga divalidasi oleh ahli Penelitian dan Evaluasi Pendidikan, sedangkan uji reliabilatas untuk instrumen penilaian proyek dilakukan melalui pelibatan dua orang penilai yang kemudian hasilnya dikorelasikan (Grounlund \& Waugh, 2009:65). Data hasil uji produk awal (uji formatif), produk akhir, tanggapan guru dan siswa dianalisis menggunakan teknik deskriptif kuantitatif. Untuk data efektivitas model, berupa perbedaan keinovatifan siswa antara kelas eksperimen dengan kelas kontrol dianalisis menggunakan uji t sampel independen (independent-samples $t$ test). Sebelum uji beda dilakukan uji persyaratan analisis yang berupa uji homogenitas.

\section{HASIL DAN PEMBAHASAN}

Bagian ini dipaparkan tentang hasil uji validitas dan reliabilitas instrumen, hasil produk awal, uji produk akhir melalui quasi eksperimen, dan pembahasan.

\section{Hasil Uji Validitas dan Reliabilitas}

Hasil uji validitas isi oleh ahli penelitian dan evaluasi pendidikan menunjukkan rata-rata penilaian terhadap keseluruhan instrumen sebesar 4.62 pada kategori valid. Selanjutnya, hasil korelasi skor keinovatifan siswa antara dua penilai, baik untuk kelas eksperimen maupun kontrol menunjukkan nilai koofisien korelasi yang tinggi dengan nilai probabilitas di bawah 0,05 . Dengan demikian, kedua instrumen dinyatakan reliabel (Tabel 1). Sebelum dikorelasikan, kedua kelas disepadankan terlebih dahulu.

\section{Hasil Uji Produk Awal}

Uji coba produk awal dilakukan melalui uji coba terbatas, yang didahului dengan uji terhadap produk buku ajar. Uji formatif ini dilakukan dengan melibatkan 12 orang siswa yang dipilih secara purposive dengan memperhatikan tingkat IQ (intelegensi) dan minat wirausaha untuk mengetahui kemenarikan, keterbacaan, dan kemudahaan memahami. Hasil uji formatif terangkum dalam Tabel 2.

Data Tabel 2 menunjukkan bahwa sebagian besar subjek/siswa menilai buku ajar yang dihasilkan layak untuk digunakan. Meskipun demikian, dilakukan perbaikan untuk komponen-komponen yang skornya rendah, seperti: cover, penggunaan bahasa, urutan sajian, dan isinya. Beberapa gam-

Tabel 1. Rangkuman Hasil Uji Reliabilitas Instrumen Uji Coba

\begin{tabular}{llcccccc}
\hline \multicolumn{1}{c}{ Instrumen } & Kelas & Penilai & Rata $^{2}$ & Sd. & Nilai r & Sig. & Simpulan \\
\hline \multirow{2}{*}{ Keinovatifan } & \multirow{2}{*}{ Eksperimen } & 1 & 87.83 & 5.109 & \multirow{2}{*}{.934} & \multirow{2}{*}{.000} & \multirow{2}{*}{ Reliabel } \\
Siswa & 2 & 88.13 & 4.077 & & & \\
& \multirow{2}{*}{ Kontrol } & 1 & 72.75 & 4.442 & \multirow{2}{*}{.931} & .000 & \multirow{2}{*}{ Reliabel } \\
\hline
\end{tabular}

Tabel 2. Hasil Uji Formatif Buku Ajar Prakarya dan Kewirausahaan Berbasis Ekonomi Kreatif Berdimensi Industri Keunggulan Lokal

\begin{tabular}{clcc}
\hline No. & \multicolumn{1}{c}{ Aspek Penilaian } & Rata $^{2}$ Penilaian* & Kategori Penilaian** \\
\hline 1. & Desain cover menarik & 4.1 & Sangat baik \\
2. & Gambarnya menarik & 4.2 & Sangat baik \\
3. & Jenis dan tampilan huruf sesuai & 4.2 & Sangat baik \\
4. & Bahasanya mudah difahami & 4.1 & Sangat baik \\
5. & Desain isi menarik & 4.4 & Sangat baik \\
6. & Urutan sajian runtut & 4.2 & Sangat baik \\
7. & Isinya mudah difahami & 4.0 & Sangat baik \\
8. & Buku menarik minat belajar & 4.4 & Sangat baik \\
\hline Keseluruhan & 4.2 & Sangat baik \\
\hline Keterangan: & \\
$*$ & Skor penilaian berada pada interval $1-5$ & \\
$* *$ & Kriteria: $p s>4$ (Sangat baik); $3<p s \leq 4$ (Baik); $2<p s \leq 3$ (Cukup); $1<p s \leq 2$ (Kurang); dan \\
\hline & $p s=1$ (Sangat kurang), dengan $p s$ adalah penilaian Siswa terhadap buku ajar \\
\hline
\end{tabular}


bar diperbaiki baik ukuran, tata letak, maupun kejelasannya dan lainnya.

Setelah dilakukan revisi terhadap hasil uji formatif, baru dilanjutkan dengan uji coba terbatas. Dalam uji terbatas ini terdiri dari 2 (dua) siklus untuk materi konsep dan jenis kain batik serta materi peralatan dan bahan produksi. Selanjutnya dalam setiap siklus terdiri dari 3 (tiga) pertemuan atau tindakan. Tahap perencanaan berkaitan dengan pengaturan jadwal, materi, persiapan pembelajaran, persiapan bahan dan alat praktik, pelatihan dan simulasi dengan guru mata pelajaran, persiapan buku ajar, silabus, RPP, panduan pembelajaran, dan lainnya. Tahapan pelaksanaan merupakan implementasi pembelajaran atau praktik berdasarkan perencanaan yang sudah dibuat. Tahap observasi merupakan pengamatan selama proses pembelajaran atau praktik yang dilakukan oleh peneliti. Sedangkan tahap refleksi merupakan kegiatan perenungan, analisis, dan evaluasi terhadap proses pembelajaran yang dilakukan. Secara keseluruhan, hasil uji coba terbatas menunjukkan bahwa model yang dihasilkan komprehensif, mudah digunakan, dan dilihat dari keinovatifan siswa menunjukkan trend peningkatan.

\section{Keefektifan Model}

Data keinovatifan Siswa dalam menciptakan produk berbasis ekonomi kreatif berdimensi industri keunggulan lokal diperoleh dari penilaian berbasis proyek yang dilakukan oleh 2 (dua) orang penilai. Uji beda keinovatifan kedua kelompok kelas didahului dengan uji persyaratan analisis, berupa uji homogenitas. Hasil uji homogenitas menunjukkan besaran nilai $\mathrm{F}_{\text {hitung }}$ sebesar 0,454 dengan nilai probabilitas sebesar 0,501 >0,05. Hasil ini juga disandingkan dengan hasil test of homogeneity of variance, dimana diperoleh nilai based mean yang sama, yaitu 0,454 dengan nilai probabilitas sebesar 0,501 >0,05. Dengan kedua teknik tersebut, dapat disimpulkan bahwa varians kedua kelas adalah homogen.

Berdasarkan hasil uji persyaratan tersebut, maka dilanjutkan dengan uji beda terhadap capaian keinovatifan Siswa. Data hasil uji t keinovatifan kedua kelompok ditunjukkan oleh Tabel 3 berikut.

Berdasarkan hasil tersebut dapat disimpulkan bahwa terdapat perbedaan yang signifikan keinovatifan Siswa dalam menciptakan produk ekonomi kreatif berdimensi industri keunggulan lokal antara kelas eksperimen dengan kelas kontrol, dimana keinovatifan kelas eksperimen lebih tinggi dibandingkan kelas kontrol. Hal ini ditunjukkan dengan nilai rata-rata keinovatifan Siswa pada kelas eksperimen jauh lebih tinggi. Perbedaan ini dapat difahami, karena konten pembelajaran pada kelas eksperimen disesuaikan dengan kebutuhan Siswa dan proses pembelaja-

Tabel 3. Rangkuman Hasil Uji t Keinovatifan Siswa Kelas Eksperimen dan Kelas Kontrol

\begin{tabular}{|c|c|c|c|c|c|c|c|}
\hline Variabel & $\begin{array}{c}\text { Kelas/ } \\
\text { Kelompok }\end{array}$ & $\mathrm{N}$ & Rata $^{2}$ & Sd. & Nilai t & Df & Sig. \\
\hline \multirow{2}{*}{$\begin{array}{l}\text { Keinovatifan } \\
\text { Siswa }\end{array}$} & Eksperimen & 88 & 88.02 & 4.480 & \multirow{2}{*}{30.804} & \multirow{2}{*}{174} & \multirow{2}{*}{.000} \\
\hline & Kontrol & 88 & 67.00 & 4.574 & & & \\
\hline
\end{tabular}

Sumber: Pengolahan Data Primer

Tabel 4. Tanggapan Guru Terhadap Model Prakarya dan Kewirausahaan Berbasis Ekonomi Kreatif Berdimensi Industri Keunggulan Lokal

\begin{tabular}{clccc}
\hline No & \multicolumn{1}{c}{ Aspek Tanggapan } & $\begin{array}{c}\text { Rata }^{2} \\
\text { Tanggapan* }^{*}\end{array}$ & $\begin{array}{c}\text { Standar } \\
\text { Deviasi }\end{array}$ & $\begin{array}{c}\text { Kategori } \\
\text { Tanggapan** }\end{array}$ \\
\hline 1 & Relevance & 5.00 & 0.00 & Sangat Baik \\
\hline 2 & Reflection & 4.38 & 0.52 & Sangat Baik \\
\hline 3 & Interaction & 4.13 & 0.40 & Sangat Baik \\
\hline 4 & Tutor Support & 4.87 & 0.35 & Sangat Baik \\
\hline 5 & Peer Support & 4.63 & 0.52 & Sangat Baik \\
\hline 6 & Interpretation & 4.62 & 0.52 & Sangat Baik \\
\hline & Keseluruhan & 4.60 & 0.49 & Sangat Baik \\
\hline $\begin{array}{l}\text { Keterangan: } \\
* \\
* *\end{array}$ & $\begin{array}{l}\text { Skor tanggapan berada pada interval 1-5 } \\
\text { Kriteria: } t g>4 \text { (Sangat baik); } 3<t g \leq 4 \text { (Baik); } 2<t g \leq 3 \text { (Cukup); } 1<t g \leq 2 \text { (Kurang); dan } t g=1 \text { (Sangat }\end{array}$ \\
& kurang), dengan tg adalah tanggapan guru terhadap model \\
\hline Sumber: Pengolahan Data Primer &
\end{tabular}


rannya lebih mengedepankan kegiatan bersama, interaksi, dan kerjasama yang dipadukan dengan kegiatan praktik.

\section{Tanggapan Guru dan Siswa Terhadap Model}

Tanggapan guru Prakarya dan Kewirausahaan dan Siswa divisualisasikan dalam Tabel 4 dan 5 .

Berdasarkan Tabel 4 diketahui bahwa secara keseluruhan guru Prakarya dan Kewirausahaan memberikan tanggapan yang sangat baik terhadap model Prakarya dan Kewirausahaan ekonomi kreatif berdimensi industri keunggulan lokal. Penilaian atau tanggapan tertinggi pada aspek relevance dan terendah pada aspek interaction. Tingginya tanggapan terhadap aspek relevance lebih didasarkan pada realita yang dihadapi guru, berupa kesulitan dalam mengembangkan pembelajaran Prakarya dan Kewirausahaan yang sesuai dengan permasalahan dan kebutuhan Siswa. Model yang dihasilkan telah membantu guru dalam meningkatkan relevansi pembelajaran Prakarya dan Kewirausahaan dengan permasalahan dan kebutuhan dimaksud. Sementara itu, aspek interaction memperoleh tanggapan terendah, meskipun masih pada kategori yang sangat baik. Hal ini dapat difahami, karena guru kurang terbiasa membangun komunikasi dan interaksi secara intensif.

Siswa kelas eksperimen memberikan tanggapan yang positif dan sangat baik terhadap model Prakarya dan Kewirausahaan ekonomi kreatif berdimensi industri keunggulan lokal. Penilaian atau tanggapan tertinggi pada aspek tutor support dan terendah pada aspek interpretation. Berbeda dengan tanggapan guru, siswa memberikan tang- gapan yang sangat baik pada aspek tutor support dibanding aspek relevance. Hal ini terjadi karena siswa mendapatkan dukungan, bimbingan, dan arahan secara langsung oleh guru dan pengrajin dan dunia industri. Setiap mengalami kesulitan, selalu diberikan bimbingan langsung oleh keduanya, khususnya oleh pengrajin pada saat praktik.

\section{Revisi Model Akhir}

Muara dari serangkaian proses pengujian, baik melalui uji produk awal maupun uji produk akhir adalah diperolehnya model akhir model Prakarya dan Kewirausahaan berbasis ekonomi kreatif berdimensi industri keunggulan lokal. Selama proses pengujian diperoleh berbagai masukan untuk perbaikan model sehingga dihasilkan model final. Namun demikian, sebagai catatan bahwa perbaikan model lebih banyak bersifat teknis daripada perbaikan substansi model yang dihasilkan. Deskripsi model akhir ditampilkan pada Tabel 6.

\section{Pembahasan}

Kriteria keefektifan model prakarya dan kewirausahaan yang dihasilkan adalah keinovatifan siswa dalam menghasilkan produk ekonomi kreatif berdimensi industri keunggulan lokal. Hasil uji menunjukkan nilai $t_{\text {hitung }}$ sebesar 30,804 dengan nilai probabilitas sebesar 0,000 . Artinya bahwa model prakarya dan kewirausahaan yang dihasilkan efektif ditinjau dari keinovatifan siswa. Keinovatifan tersebut tercermin dari: motif berbeda dalam desain kerajinan batik, penggunaan cara pengerjaan atau proses produksi yang lebih sederhana, proses pemasaran dengan memanfaat-

Tabel 5. Tanggapan Siswa Terhadap Model Prakarya dan Kewirausahaan Berbasis Ekonomi Kreatif Berdimensi Industri Keunggulan Lokal

\begin{tabular}{|c|c|c|c|c|}
\hline No & Aspek Tanggapan & $\begin{array}{c}\text { Rata }^{2} \\
\text { Tanggapan* }\end{array}$ & $\begin{array}{l}\text { Standar } \\
\text { Deviasi }\end{array}$ & $\begin{array}{c}\text { Kategori } \\
\text { Tanggapan** }\end{array}$ \\
\hline 1 & Relevance & 4.30 & 0.63 & Sangat Baik \\
\hline 2 & Reflection & 4.32 & 0.67 & Sangat Baik \\
\hline 3 & Interaction & 4.26 & 0.70 & Sangat Baik \\
\hline 4 & Tutor Support & 4.49 & 0.63 & Sangat Baik \\
\hline 5 & Peer Support & 4.42 & 0.68 & Sangat Baik \\
\hline 6 & Interpretation & 4.25 & 0.75 & Sangat Baik \\
\hline & Keseluruhan & 4.34 & 0.68 & Sangat Baik \\
\hline $\begin{array}{l}\text { Keter: } \\
* \\
* *\end{array}$ & \multicolumn{4}{|c|}{$\begin{array}{l}\text { Skor tanggapan berada pada interval } 1-5 \\
\text { Kriteria: } \operatorname{tg}>4 \text { (Sangat baik); } 3<\operatorname{tg} \leq 4 \text { (Baik); } 2<\operatorname{tg} \leq 3 \text { (Cukup); } 1<\operatorname{tg} \leq 2 \text { (Kurang); dan } \operatorname{tg}=1 \text { (Sangat } \\
\text { kurang), dengan } t g \text { adalah tanggapan guru terhadap model }\end{array}$} \\
\hline
\end{tabular}


Tabel 6. Deskripsi Model Akhir Prakarya dan Kewirausahaan Berbasis Ekonomi Kreatif Berdimensi Industri Keunggulan Lokal

\begin{tabular}{|c|c|c|}
\hline No. & $\begin{array}{l}\text { Komponen } \\
\text { Model }\end{array}$ & Penjelasan \\
\hline 1. & $\begin{array}{l}\text { Tujuan } \\
\text { Pembelajaran }\end{array}$ & $\begin{array}{l}\text { Komponen ini tidak berbeda dengan rancangan awal. Strukturnya tetap } \\
\text { mengikuti kebijakan pendidikan atau mata pelajaran lain yang memuat: } \\
\text { - Tujuan Mata Pelajaran } \\
\text { Tujuan ditekankan pada keinovatifan sebagai fokus utama. Tujuan ini } \\
\text { mengacu pada keseluruhan isi mata pelajaran Prakarya dan } \\
\text { Kewirausahaan baik struktur orientasi maupun pendukung untuk satu } \\
\text { tahun. } \\
\text { Kompetensi Inti } \\
\text { Komptensi ini mengacu pada kompetensi inti mata pelajaran Prakarya } \\
\text { dan Kewirausahaan yang sudah ditetapkan oleh Kementerian } \\
\text { Pendidikan dan Kebudayaan } \\
\text { Kompetensi Dasar } \\
\text { KD bersifat urut, bersentuhan langsung dengan skill atau keterampilan } \\
\text { membuat produk/jasa, konstruksi ke arah tujuan orientatif prosedural } \\
\text { dan tujuan pendukung prasyarat, jelas sasaran, formulasi dalam bentuk } \\
\text { yang operasional, dan berbentuk produk belajar. } \\
\text { Indikator Pencapaian Kompetensi } \\
\text { Menjadi penanda ketercapaian KD, bersentuhan langsung dengan skill } \\
\text { dalam menciptakan produk/jasa, konstruksi ke arah tujuan orientatif } \\
\text { prosedural dan tujuan pendukung prasyarat, jelas sasarannya, formulasi } \\
\text { dalam bentuk yang operasional, berbentuk produk belajar, dan } \\
\text { mengandung satu tujuan belajar. }\end{array}$ \\
\hline 2. & \multicolumn{2}{|c|}{ Prosedur Pembelajaran } \\
\hline & $\begin{array}{l}\text { a. Pengorgani- } \\
\text { sasian Materi }\end{array}$ & $\begin{array}{l}\text { - Sesuai dengan prinsip rekonstruksi sosial, maka pengorganisasian } \\
\text { materi tetap difokuskan pada penataan materi, penyajian kompetensi } \\
\text { dasar dan indikator pencapaian kompetensi, desain teks dan gambar, } \\
\text { rangkuman, evaluasi, tugas/latihan, daftar pustaka, dan glossary. } \\
\text { - Pengurutan materi tetap menggunakan pendekatan prosedural prasyarat } \\
\text { yang menunjukkan urutan-urutan dalam menampilkan langkah-langkah } \\
\text { prosedur produksi. Khusus untuk teks ditampilkan dalam bentuk } \\
\text { latihan atau petunjuk kegiatan yang dilakukan sehingga tidak ada kesan } \\
\text { menghafal. } \\
\text { Pada setiap tahapan atau inti materi disajikan secara komunikatif } \\
\text { dengan dukungan ilustrasi (gambar) berwarna. Teks diatur dengan set } \\
\text { up margin yang sesuai, pilihan huruf yang tepat, dan gambar didesain } \\
\text { dengan penuh arti agar dapat memperkuat pesan menjadi menarik. }\end{array}$ \\
\hline & $\begin{array}{l}\text { b.Penyampaian } \\
\text { Materi }\end{array}$ & $\begin{array}{l}\text { Pada komponen ini tidak terdapat perbedaan mendasar dengan rancangan } \\
\text { awal. Penyampaian materi dilakukan berdasarkan prinsip-prinsip } \\
\text { rekonstruksi sosial, seperti pembelajaran sebagai kegiatan bersama, } \\
\text { interaksi, dan kerjasama yang dipadukan dengan praktik langsung. } \\
\text { Implementasinya diwujudkan dalam bentuk: } \\
\text { - Pembelajaran dalam kelompok belajar, dimana dalam setiap kelompok } \\
\text { belajar memiliki struktur yang jelas dan pembagian tugas yang jelas } \\
\text { pula baik selama belajar di dalam kelas maupun praktik di luar kelas; } \\
\text { Tatap muka, dimana tatap muka pertama dilakukan di dalam kelas } \\
\text { untuk menelaah dan mendiskusikan materi pembelajaran setiap } \\
\text { bab/materi pokok dan tatap muka kedua dilakukan dalam bentuk } \\
\text { penyajian hasil praktik di luar kelas; dan }\end{array}$ \\
\hline
\end{tabular}




\begin{tabular}{|c|c|c|}
\hline & & $\begin{array}{l}\text { Penugasan terstruktur di luar kelas melalui praktik bersama pengrajin } \\
\text { atau dunia usaha. Dalam pelaksanaan tugas out class di lengkapi } \\
\text { dengan panduan pelaksanaan tugas beserta kriteria penilaiannya dan } \\
\text { panduan penyusunan laporan pelaksanaan tugas. }\end{array}$ \\
\hline & $\begin{array}{l}\text { c. Pengelolaan } \\
\text { Pembelajaran }\end{array}$ & $\begin{array}{l}\text { Tahapan pembelajaran mengikuti sintaks rekonstruksi sosial. Pada } \\
\text { komponen ini juga tidak terdapat perbedaan dengan rancangan awal. } \\
\text { - Pengaktifan pengetahuan awal dengan durasi 5-10 menit; } \\
\text { - } \quad \text { Penyajian pengetahuan baru dilakukan dengan metode aktif dan } \\
\text { beragam, seperti curah pendapat, student have question, snowball } \\
\text { throwing, diskusi, dan lainnya dengan alokasi waktu 35-40 menit; } \\
\text { - Latihan pemahaman dilakukan dalam bentuk permainan flash card, } \\
\text { mencari pasangan dengan alokasi waktu antara 35-40 menit; } \\
\text { - Praktik di luar jam pelajaran (out class) bersama pengrajin/DU/DK } \\
\text { yang dilakukan secara fleksibel berdasarkan kesepakatan dengan } \\
\text { pengrajin. Hasil praktik ditulis dalam bentuk laporan dan } \\
\text { dipresentasikan di dalam kelas dengan durasi waktu 70-80 menit; dan } \\
\text { - Refleksi terhadap proses dan hasil latihan. }\end{array}$ \\
\hline 3 & Penilaian & $\begin{array}{l}\text { Sesuai dengan prinsip rekonstruksi sosial dan fokus pada keinovatifan, } \\
\text { penilaian dilakukan menggunakan penilaian berbasis proyek. Komponen } \\
\text { ini juga tidak memiliki perbedaan dengan rancangan awal, mencakup: } \\
\text { - Pedoman tugas proyek secara berkelompok memuat penjelasan tugas } \\
\text { yang dilakukan Siswa mulai dari perencanaan, pelaksanaan, hasil, dan } \\
\text { pelaporan; } \\
\text { - Kriteria penilaian pada setiap aspek (perencanaan, pelaksanaan, } \\
\text { hasil/produk, dan pelaporan); } \\
\text { - Instrumen memuat perangkat tertulis untuk mengukur keinovatifan } \\
\text { Siswa yang disusun berdasarkan aspek dan kriteria penilaian; dan } \\
\text { - Rubrik penilaian yang disusun dalam bentuk skala likert yang memiliki } \\
\text { tiga option, yaitu: baik (skor 3), cukup (skor 2), dan kurang (skor 1). } \\
\text { Untuk membedakan skor setiap Siswa dalam kelompok, maka digunakan } \\
\text { lembar pengamatan terhadap kemampuan dalam penyajian lisan, yang } \\
\text { mencakup aspek: yaitu persiapan, penyajian, komunikasi non verbal, } \\
\text { komunikasi verbal, penggunaan media, pemberian tanggapan, dan } \\
\text { penguasaan isi. }\end{array}$ \\
\hline
\end{tabular}

kan teknologi informasi atau media sosial, dan inovasi lainnya.

Hasil kajian ini meneguhkan penggunaan teori rekonstruksi sosial dalam pembelajaran kewirausahaan. Paling tidak ada tiga penekanan teori ini terkait penguatan keinovatifan siswa, yaitu dari sisi substansi, proses pembelajaran, dan penilaian. Penekanan ketiga komponen tersebut relevan dengan komponen yang dikembangkan oleh ahli pembelajaran, seperti Reigeluth \& Merrill (1978:58-67; 1979:6-22) yang menempatkan komponen komponen tujuan/substansi, prosedur pembelajaran, dan evaluasi sebagai variabel pembelajaran. Kajian Samsudi (2014:312) juga menempatkan ketiga aspek ini sebagai desain model pembelajaran program produktif SMK, namun pada aspek prosedur pembelajaran direduksi sebatas metode pembelajaran.
Dari sisi substansi, keinovatifan siswa muncul tatkala susbtansi pembelajaran Prakarya dan Kewirausahaan diarahkan pada problem sosial termasuk solusi pemecahannya melalui pemanfaatan potensi keunggulan sekitar siswa sebagaimana pemikiran rekonstruksi sosial (McNeil, 2006:37). Penekanan pada keunggulan lokal, karena wirausaha adalah orang yang mampu memindahkan sumberdaya yang kurang produktif menjadi sumberdaya yang produktif sehingga memberi nilai ekonomis (Deveci \& Çepdi, 2015: 135), di samping menciptakan nilai (West, 2002). Selaras dengan pendapat itu, Mayhew dkk. (2012:832) menyatakan bahwa bahwa "inovasi merupakan proses menyedikan produk atau jasa baru atau mengembangkan dan menggunakan metode baru untuk menghasilkan barang atau jasa dengan biaya yang rendah". Orang yang 
bertindak inovatif dicirikan dengan kemampuan mengubah suatu masalah menjadi peluang, yang tahapannya menurut Tidd (Harkema \& Schout, 2008:519) adalah "start-up phase, the invention, the phase creation, innovation process, and the phase of commercializing the idea". Tanpa keinovatifan, maka wirausaha tidak berkembang sebagaimana yang disinyalir Hage (Harkema \& Schout, 2008:518), karena "inovasi adalah instrumen bagi wirausahawan" (Drucker, 1985:19). Dalam temuannya, Mayhew dkk (2012:832) menegaskan bahwa wirausahawan yang inovatif menjadi pemain utama dalam meningkatkan pertumbuhan ekonomi.

Kemampuan inovatif tersebut dapat dicapai atau dibentuk melalui pendidikan kewirausahaan (Huber, dkk, 2014), khususnya pendidikan kewirausahaan yang memanfaatkan potensi keunggulan lokal sebagai susbstansi materinya. Konten pembelajaran kewirausahaan digali dan bersumber dari sekitar Siswa, sehingga pembelajaran menjadi kontekstual dan relevan dengan praktik kehidupan Siswa. Hal ini pula yang ditegaskan oleh Keller (1983:407) bahwa materi yang relevan dengan kehidupan siswa dapat menarik minat dan motivasi belajar Siswa. Dengan demikian, konten ini relevan dengan pandangan rekonstruksi sosial, karena diarahkan pada upaya bagaimana siswa belajar mengenali permasalahan sosial dan melakukan praktik kewirausahaan sebagai alat menjawab permasalahan tersebut sehingga menghasilkan keinovatifan siswa dalam menciptakan produk ekonomi kreatif berdimensi keunggulan lokal. Temuan ini semakin meneguhkan bahwa pendidikan kewirausahaan yang bersandarkan pada teori rekonstruksi sosial (substansi materi berbasis keunggulan lokal) efektif dalam membentuk kompetensi kewirausahaan siswa (warga belajar).

Selain substansi, ketercapaian keinovatifan siswa juga tidak lepas dari proses pembelajaran Pakarya dan Kewirausahaan yang bersandarkan pada teori rekonstruksi sosial. Dalam teori rekonstruksi sosial, pembelajaran ditempatkan sebagai proses interaksi, kerjasama dan kegiatan bersama (McNeil, 2006:38) dan praktik langsung sebagaimana teruji dalam temuan sebelumnya (Sukardi dkk, 2014). Setidaknya ada lima tahapan pembelajaran yang digunakan sebagaimana menurut Zahorik (1995:14-22), yaitu pengaktifan pengetahuan awal, penyajian pengetahuan baru, latihan pemahaman, praktik, dan refleksi. Untuk mengaplikasikan tahapan tersebut, maka keseluruhan proses pembelajaran ditekankan pada penggunaan pembelajaran aktif dan kooperatif, seperti brainstorming, student have question, snowball throwing, inquiring minds what to know, penugasan terstruktur/project based learning, praktik, dan presentasi/diskusi yang disertai contoh dan catatan dari guru. Hasil kajian ini membuktikan bahwa proses pembelajaran Prakarya dan Kewirausahaan yang dilakukan menggunakan pendekatan rekonstruksi sosial teruji efektif dalam membentuk keinovatifan siswa dalam menghasilkan produk ekonomi kreatif berdimensi keunggulan lokal. Hasil kajian ini sejalan dengan temuan Breithorde dan Swiniarski (1999) yang menyimpulkan bahwa "pembelajaran kooperatif atau berkelompok memungkinkan siswa untuk saling berbagi, berinteraksi, dan bekerjasama sehingga berdampak terhadap perolehan hasil belajar". Hal ini terjadi karena dalam pembelajaran berorientasi rekonstruksi sosial, siswa (mahasiswa) saling berinteraksi dan bekerjasama, baik dengan sesama maupun lingkungan sekitarnya. Hal ini juga sejalan dengan temuan-temuan sebelumnya yang menempatkan salah satu aplikasi pembelajaran berorientasi rekonstruksi sosial, yaitu project based learning yang efektif terhadap sikap, minat, perilaku wirausaha dan prestasi belajar (Mulyani, 2014) termasuk dalam membentuk karakteristik kewirausahaan (Samsudi, 2014).

Selain interaksi, kerjasama, dan kegiatan bersama dalam proses pembelajaran Prakarya dan Kewirausahaan, maka temuan menarik adalah pentingnya dipadukan kegiatan pembelajaran tersebut dengan praktik langsung. Model akhir Prakarya dan Kewirausahaan yang dihasilkan ini melakukan pembaharuan/koreksi terhadap teori rekonstruksi sosial. Pembelajaran Prakarya dan Kewirausahaan tidak hanya diwujudkan dalam bentuk kegiatan bersama, interaksi, dan kerjasama dalam membangun pengetahuan berdasarkan realitas atau permasalahan sosial, melainkan juga dilakukan melalui praktik secara langsung. Praktik dilakukan di luar kelas bersama pengrajin/dunia industri dikarenakan praktik tersebut dapat membentuk kemampuan kewirausahaan (Mayhew dkk., 2016:425). Praktik ini menjadi alat atau solusi terhadap permasalahan sosial, seperti lemahnya skill yang berdampak pada pengangguran. Praktik langsung menjadi penting dalam membentuk keinovatifan Siswa, karena jauh sebelumnya Plaschka dan Welsch 
(1990) dalam temuannya menyebutkan bahwa pembelajaran praktik berbasis realitas merupakan model pembelajaran yang efektif untuk mencapai hasil belajar (keinovatifan). Temuan ini sekaligus meneguhkan kajian Solomon (2007) bahwa praktik kewirausahaan bersama pengusaha sangat efektif dalam membentuk kemampuan Siswa (khususnya keinovatifan). Baumol (Mayhew dkk., 2012:832-833) menyatakan bahwa pembelajaran dalam bentuk praktik mendorong individu membuat terobosan baru dalam menciptakan produk. Praktik memungkinkan Siswa untuk menerapkan pengetahuan sehingga menjadi solusi terbaik dalam menghasilkan lulusan yang menjadi wirausahawan yang inovatif (Mayhew dkk., 2016:426).

Vanevenhoven (2013) juga menyebutkan bahwa keinovatifan dapat dibentuk tatakala Siswa berinteraksi dan berlatih langsung dengan pengusaha/pengarajin/ dunia usaha. Selain itu, untuk berinteraksi dan berlatih dengan pengusaha/pengrajin, maka pembelajaran (praktik) dilakukan tidak hanya di setting kelas melainkan di luar kelas. Pembelajaran atau praktik di luar kelas didasarkan pada konsep bahwa potensi ekonomi kreatif berdimensi industri keunggulan lokal merupakan sumber belajar berbasis lingkungan yang dapat dimanfatkan oleh siswa. Pengelolaan pembelajaran ini relevan denga pemikiran Vigotsky (Schunk, 2012:337) yang menyebutkan pentingnya diberikan bantuan belajar oleh orang dewasa/lingkungan (praktik langsung bersama pengrajin/DU/DK) dan secara perlahan dikurangi sampai Siswa mampu mempraktikkan atau memproduksi sendiri. Dengan demikian, pembelajaran di luar kelas memberikan peluang kepada Siswa untuk memperoleh pengetahuan dan keterampilan melalui pelibatan dalam dunia nyata. Pembelajaran di luar kelas juga dapat menghindari kejenuhan, kebosanan, dan persepsi belajar hanya di dalam kelas.

Dengan proses pembelajaran Prakarya dan Kewirausahaan tersebut, selain efektif terhadap keinovatifan siswa juga mendapatkan respon yang positif. Hasil ini sejalan dengan temuan Sthapornnanon dkk (2009) yang menemukan bahwa pembelajaran rekonstruksi sosial mendapatkan respon yang positif dari siswa karena dapat meningkatkan relevansinya dengan kebutuhan siswa, mendorong siswa melakukan refleksi, meningkatkan interaksi, mendorong guru memberikan support, mendorong sesama siswa saling membantu, dan kemampuan menginterpretasi hasil belajar.

Komponen terakhir penggunaan teori rekonstruksi sosial dalam prakarya dan kewirausahaan adalah pada aspek penilaian pembelajarannnya. Implikasi dari substansi dan proses pembelajaran prakarya dan kewirausahaan di atas, maka penggunaan tes tertulis tidak relevan dikarenakan tidak dapat mengungkapkan keinovatifan siswa. Oleh karenanya, penggunaan berbasis bukti nyata dengan melibatkan siswa dalam wujud penilaian berbasis proyek relevan digunakan. Penilaian proyek dapat menilai unjuk kerja (proses) sekaligus hasil praktik (produk) yang dilakukan oleh Siswa, baik yang dilakukan sendiri oleh Siswa, teman sejawat, maupun oleh guru (Bergh dkk, 2006; Puskur Balitbang, 2006:36). Hasil kajian ini menunjukkan kelayakan penggunaan penilaian proyek untuk mengukur kenovatifan siswa. Hasil kajian ini sejalan dengan temuan Doppelt (2003) bahwa penilaian berbasis proyek efektif dalam mengukur kompetensi dan ketrampilan siswa karena mampu memberikan pengalaman nyata selama proses penyelesaian proyek. Kajian sebelumnya juga menemukan bahwa penilaian yang bersandarkan pada teori rekonstruksi sosial ini teruji mampu mengukur kompetensi kewirausahaan, khususnya kecakapan vokasional.

\section{SIMPULAN}

Berdasarkan pemaparan di atas, maka dapat disimpulkan sebagai berikut. Pertama, hasil uji produk awal melalui uji formatif oleh siswa menunjukkan bahwa design model yang dihasilkan (khususnya produk buku ajar) sangat baik, dilihat dari kemenarikan, keterbacaan, dan kemudahaan memahami sehingga layak diuji lebih lanjut. Kedua, hasil uji produk akhir melalui quasi eksperimen menunjukkan bahwa model yang dihasilkan efektif ditinjau dari parameter keinovatifan Siswa dalam menghasilkan produk-produk ekonomi kreatif berdimensi industri keunggulan lokal. Hasil uji perbandingan menunjukkan bahwa terdapat perbedaan yang signifikan keinovatifan Siswa antara kelas eksperimen dengan kelas kontrol, dimana keinovatifan Siswa kelas eksperimen lebih tinggi dibandingkan kelas kontrol. Ketiga, model akhir yang dihasilkan memperoleh tanggapan yang sangat baik dari siswa maupun guru. Guru dan siswa memberikan respon yang positif dan sangat baik terhadap model yang dihasilkan dilihat dari aspek relevance, reflection, interac- 
tion, tutor support, peer support, dan interpretation. Keempat, dari serangkain proses uji di atas diperoleh model akhir yang dihasilkan mencakup beberapa komponen utama, yaitu: tujuan pembelajaran, prosedur pembelajaran (pengorganisasian materi, penyampaian materi, dan pengelolaan pembelajaran), dan penilaian. Dari rancangan model, dihasilkan produk, berupa: rumusan kompetensi dasar, silabus, buku ajar, buku panduan pembelajaran, media, rencana pelaksanaan pembelajaran, dan perangkat penilaian.

\section{UCAPAN TERIMA KASIH}

Penelitian ini dibiayai dari Skim Hibah Strategis Nasional 2016. Untuk itu, ucapan terima kasih disampaikan kepada Direktorat Jenderal Penguatan Riset dan Pengembangan Kementerian Ristek dan Dikti atas bantuan dan dukungannya serta Universitas Mataram telah menfasilitasi selama kegiatan penelitian. Terima kasih pula disampaikan kepada Dewan Redaksi Cakrawala Pendidikan beserta staf atas perkenan dipublikasikannya hasil penelitian ini.

\section{DAFTAR PUSTAKA}

Altinay, L., Madanoglu, M., Daniele, R., \& Lashley, C. 2012. "The Influence of Family Tradition and Psychological Traist on Entrepreneurial Intention". International Journal of Hospitally Management. 31 (2): 489-499.

Ary, D., Jacobs, L. C., \& Razavieh, A. 2002. Introduction to Research in Education. Belmont United State: Wadsworth/Thomson Learning Group.

Badan Pusat Statistik/BPS. 2016a. Pengangguran Terbuka Menurut Pendidikan Tertinggi yang Ditamatkan 1986-2016. (Online), (https://www.bps.go.id/link TabelStatis/ view/id/972), diakses 2 November 2016.

Badan Pusat Statistik/BPS. 2016b. Indikator Pendidikan 1994-2015. (Online), (https:// www.bps.go.id/linkTabelStatis/view/ id/1525), diakses 2 November 2016.

Bergh, V. V. D., Mortelmans, D., Spooren, P., Petegem, P. V., Gijbels, D., \& Vanthournout, G. 2006. "New Assessment Modes Within Project-Based Education-The
Stakeholderes". Studies in Educational Evaluation, 32: 345-368.

Borg, W. R. \& Gall, M. D. 1983. Educational Research: an Introduction ( $4^{\text {th }}$ ed.). New York: Longman, Inc.

Breithorde, M. L. \& Swiniarski, L. 1999. "Constructivisme and Reconstructionism: Educating Teachers for World Citizenship". Australian Journal of Teacher Education, 24 (1): 1-16.

Byrne, J., Fayolle, A., \& Toutain, O. Entrepreneurship Education: What We Know and What We Need to Know. In E. Chel \& M. KarataOzkan (eds). 2014. Handbook of Research on Small Business and Entrepreneurship. Cheltenham, UK: Edward Elgar.

Deveci, Ì. \& Çepdi, S. 2015. "Examining Science Teacher Candidates' Entrepreneurial Characteristics According to Some Variables". International Online Journal of Educational Sciences. 7 (3): 135-149.

Doppelt, Y. 2003. "Implementation and Assessment of Project-Based Learning in a Flexible Environment". International Journal of Technology and Design Education, (13): 255-272.

Drucker, P. F. 1985. Innovation and Entrepreneurship. New York: Harper And Row.

Fayolle, A. 2008. "Entrepreneurship educationat a Crossroads: Towards a More Mature Teaching Field". Journal of Enterprising Culture, 16 (4): 325-701.

Grounlund, N.E. \& Waugh, C.K. 2009. Assessment of Student Achievement ( $9^{\text {th }}$ ed.). New Jersey: Pearson Education, Inc.

Harkema, S. J. M. \& Schout, H. 2008. "Incorporating Student-Centred Learning in Innovation and Enrepreneurship Education". European Journal of Education, 43 (4): 513-526.

Huber, L. R., Sloof, R., \& Van Praag, M. 2014. The Effect of Early Entrepreneurship Edu- 
cation: Evidence from a Field Experiment. European Economic Review, 72: 76-97.

Jha, A. K. 2012. Epistemological and Pedagogical Concerns of Constructionism: Relating to the Educational Practices. Creative Education, 3 (2): 171-178.

Keller, J. M. Motivational Design of Instruction. Dalam Charles M. Reigeluth (Ed). 1983. Instructional-Design Theories and Models: An Overview of their Current Status. Hillsdale, N.J.: Lawrence Erlbaum Associates.

Kuratko, D. F. 2005. "The Emergence of Entrepreneurship Education: Development, Trends, and Challenges". Entrepreneurship Theory and Practice, 29 (5): 577-589.

Macdonald, S. 2013. Beyond the Creative Industries. International Journal of Education Through Art, 9 (3): 293-309.

Man, T. W. Y. \& Yu, C. W. M. 2007. Social Interaction and Adolescent's Learning in Enterprise Education: an Empirical Study. Education + Tarining, 49 (8): 620-633.

Mayhew, M. J., Simonoff, J. S., Baumol, W. J., Selznick, B. S. \& Vassallo, S. J. 2016. "Cultivating Innovative Entrepreneurs for the Twenty-First Century: A Study of U.S. and German Studens". The Journal of Higher Education, 87 (3): 420-455.

Mayhew, M. J., Simonoff, J. S., Baumol, W. J., Wiesenfeld, B. M., \& Klein, M.W. 2012. Exploring Innovative Entrepreneurship and Its Ties to Higher Educational Experiences. Res High Educ, 53: 831-859.

McNeil, J. D. 2006. Contemporary Curriculum: In Thought and Action. NJ: John Wiley and Sons, Inc.

Mulyani, E. 2014. "Pengembangan Model Pembelajaan Berbasis Projek Pendidikan Kewirausahaan untuk Meningkatkan Sikap, Minat, Perilaku Wirausaha, dan Prestasi Belajar Siswa SMK". Cakrawala Pendidikan, 33 (1): 50-61.
Murwani, F. D. 2016. Model Pendidikan Entrepreneurship di Perguruan Tinggi: Upaya Menumbuhkan Entrepreneur dan Intrapreneur dalam Wadah Entrepreneurial University. Pidato Pengukuhan Guru Besar Bidang Pendidikan Ekonomi pada Fakultas Ekonomi Universitas Negeri Malang, 14 April.

Plaschka, G. R. \& Welsch, H. P. 1990. "Emerging Structures in Entrepreneurship Education: Curricula Designs and Strategies". Entrepreneurship Theory and Practice, 14 (3): 55-71.

Pusat Kurikulum Badan Penelitian dan Pengembangan/Puskur Balitbang. 2006. Model Penilaian Kelas. Jakarta: Puskur Balitbang Depdiknas.

Rauch, A. \& Frese, M. 2007. "Let's Put The Person Back Into Entrepreneurship Research: A Meta Analysis on The Relationship Between Business Owners' Personality Traits, Buusiness Creation, and Success". European Journal of Work and Organizational Psycholoy, 16 (4): 353-385.

Rautkorpi, T. 2007. "Mentoring in the Creative Economy". International Journal of Education Through Art, 3 (3): 231-241.

Reigeluth, C. M. \& Merrill, M. D. 1978. “A Knowledge Base for Improving Our Methods of Instructional". Educational Psychologist, 13: 57-70.

Reigeluth, C. M. \& Merrill, M. D. 1979. "Classes of Instructional Variables". Educational Technology, 19 (3): 5-24.

Samsudi. 2014. "Pengembangan Model Pembelajaran Program Produktif SMK untuk Membentuk Karakter Kewirausahaan Lulusan". Cakrawala Pendidikan, 33 (2): 307-314.

Schunk, D. H. Teori-teori Pembelajaran: Perspektif Pendidikan. ( $6^{\text {th }}$ ed.). Terjemahan Eva Hamdiah dan Rahmat Fajar. 2012. Yogyakarta: Pustaka Pelajar. 
Solomon, G. T. 2007. "An Examination of Enrepreneurship Education in The United States". Journal of Small Business and Enterprise Development, 14 (2): 168-182.

Sthapornnanon, N., Sakulbumrungsil, R., Theeraroungchaisri, \& Watcharadamrongkun, S. 2009. "Social Constructivist Learning Environment in an Online Professional Practice Course". American Journal of Pharmaceutical Education, 73 (1): 1-8.

Sukardi, Ismail, M., \& Suryanti, N. M. N. 2014. "Model Pendidikan Kewirausahaan Berbasis Keterampilan Lokal Bagi Anak Putus Sekolah pada Masyarakat Marginal”. Cakrawala Pendidikan, 33 (3):402-412.

Sukardi. 2016. "Design Model Prakarya dan Kewirausahaan Berbasis Ekonomi Kreatif Berdimensi Industri Keunggulan Lokal”. Cakrawala Pendidikan, 35 (1):114-124.
Vanevenhoven, J. 2013. "Advances and Challenges in Entrepreneurship Education". Journal of Small Business Economics, 29: 351-382.

West, M. A. 2002. "Sparkling Fountains or Stagnant Ponds: An Integrative Model of Creativity and Innovation Implementation in Work Groups". Applied Psychology: An International Review, 51 (3): 355-387.

Willis, J. 2000. The Maturing of Constructivist Instructional Design: Some Basic Principles That Can Guide Practice. Educational Technology, 40 (1): 5-16.

Zahorik, J. A. 1995. Constructivist Teaching. Bloomingthon Indiana: Phi-Delta Kappa Educational Foundation.

Zimmerer, T.W., Scarborough, N. M. \& Widson, D. 2008. Essentials of Entrepreneurship and Small Business Management ( $5^{\text {th }} \mathrm{ed}$ ). Upper Saddle Rever, NJ: Pearson Education, Inc. 